\begin{tabular}{rr} 
çağdaş & Yaratıcı Drama Dergisi 2019, 14(2), 281-296 \\
drama & www.yader.org \\
\hline
\end{tabular}

\title{
Çocuk ve Drama Dersi Veren Öğretim Elemanlarının Niteliklerine İlişkin Çocuk Gelişimi Programı Öğrencilerinin Görüşseri
}

\section{Ömer Nayci ${ }^{1}$}

\begin{tabular}{|c|c|}
\hline Makale Bilgisi & Öz \\
\hline DOI: $10.21612 /$ yader.2019.016 & Bu çalışmada üniversitelerin meslekyüksekokulları bünyesindeyer alan Çocuk Gelişimi \\
\hline Makale Geçmişi & $\begin{array}{l}\text { Programında ögrenim gören ögrencilerin almış oldukları çocuk ve drama dersini } \\
\text { veren öğretim elemanlarının niteliklerine ilișkin ögrenci görüşlerinin belirlenmesi }\end{array}$ \\
\hline Geliş tarihi & amaçlanmıştır. Araştırma tarama türünde nitel bir araştırmadır. Araştırmanın çalışma \\
\hline Kabul & $\begin{array}{l}\text { grubunu 2018-2019 ĕgitim öğretim yılında üniversitelerin meslek yüksekokulları } \\
\text { Çocuk Gelişimi Programlarında ögrenim gören, çocuk ve drama dersi alan ögrenciler } \\
\text { oluşturmuştur. Araştırma kapsamında Siirt Üniversitesi’nden } 16 \text { ögrenci, Mardin }\end{array}$ \\
\hline Anahtar Sözcükler & Artuklu Üniversitesi'nden 13 ögrenci, Batman Üniversitesi'nden 28 öğrenci ve Şırnak \\
\hline Öğretim elemanı & Üniversitesi'nden 37 ögrenci olmak üzere toplam 94 öğrenciden görü̈s alınmıştır. \\
\hline Çocuk ve drama dersi & $\begin{array}{l}\text { Araştırmada veri toplama aracı olarak görüşme formu kullanılmıştır. Bu form } \\
\text { araștırmacı tarafindan hazırlanmış olup, bir açı uçlu sorudan oluşturulmuştur. }\end{array}$ \\
\hline Nitelik & Araştırma sonucunda elde edilen veriler, içerik analizi ile analiz edilmiştir. Çocuk \\
\hline Çocuk gelişimi programı & $\begin{array}{l}\text { Gelişimi Programında öğrenim gören öğrenciler tarafindan çocuk ve drama dersini } \\
\text { veren ögretim elemanlarının niteliklerine ilişkin olarak ortak temalar dışında en çok }\end{array}$ \\
\hline Makale Türü & vurgulanan nitelikler; öğretim elemanının ĕ̆lenceli bir kişiliğe sahip olması, yeniliğe \\
\hline Araştırma Makalesi & 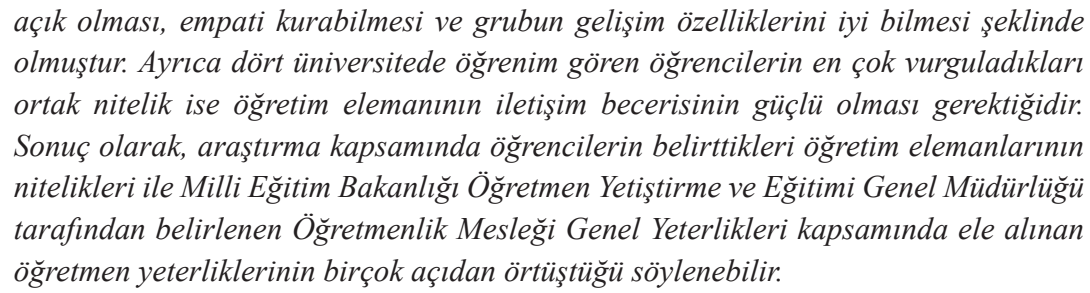 \\
\hline
\end{tabular}

1 Dr. Öğr. Üy., Şırnak Üniversitesi, Şırnak MYO, Şırnak, Türkiye. E-posta: nayciomer@gmail.com Orcid ID: https://orcid.org/0000-0002-6087-6456 


\title{
The Opinions of Child Development Programme Students Related to the Qualifications of Instructors Teaching Child and Drama Lesson
}

\begin{tabular}{lr}
\hline Article Info \\
\hline DOI: $10.21612 /$ yader.2019.016 \\
\hline Article History & \\
Received & 02.06 .2019 \\
Accepted & 12.07 .2019
\end{tabular}

\begin{abstract}
In this study, it is aimed to determine the student opinions of the students studying in Child Development Programme within the scope of vocational schools of universities related to the qualifications of instructors teaching Child and Drama lesson. The study is a qualitative research in the type of a survey. The students taking Child and Drama lesson who study in Child Development Programmes in the vocational schools of universities in 2018-2019 academic year formed the study group of the study. The opinions of 94 students were taken in total within the scope of this study;16 of them were from Siirt University, 13 from Mardin Artuklu University, 28 from Batman University and 37 from Shirnak University. Interview form was used in the study as data collection tool. This form was prepared by the researcher and it consists of one open ended question. The data obtained in consequence of the research was analysed with content analysis. The most emphasised qualifications as the qualifications of instructors teaching Child and Drama lesson emphasised by the students studying in Child Development Programme except the common themes were insructor having an entertaining personality, being open to new ideas, showing emphaty and knowing the development features of the group well. Besides, the most common qualification emphasised by the students studying in four universities was the communication skill of the instructor being strong. As a result, it can be said that the qualifications of instructors specified by the students within the scope of the research coincide in many aspects with instructor qualifications specified within the scope of Teaching Profession General Qualifications which were determined by Ministry of National Education General Directorate of Teacher Training and Education.
\end{abstract} Keywords

Instructor

Child and drama lesson, Qualification

Child development programme

Article Type

Research paper 


\section{Giriş}

Ülkelerin uygulamış oldukları eğitim sistemlerinin tarihsel süreç içerisinde ihtiyaca cevap verip vermediği sürekli tartışma konusu olmuştur. Hızlı gelişen teknoloji, toplumsal dinamiklerde birtakım değişiklilikleri de beraberinde getirmiştir. Söz konusu değişen koşullara bağlı olarak toplumun bireyden beklentileri de değişmiştir. Dolayısıyla toplum tarafindan nasıl bir birey istenildiği sorusunun yanıtlanması ihtiyacı ortaya çıkmıştır. Bu soruya bağlı olarak bireyi yetiştiren ve topluma kazandıran öğretmenin niteliği de tartışılmaya başlanmıştır. Bu durum da "Nasıl bir birey?" sorusunun yanı sıra "Nasıl bir öğretmen?" sorusunu da beraberinde getirmiştir. Bu soruya bağlı olarak öğretmenin niteliği, toplumu oluşturan temel bileşenlerin değişimiyle eşzamanlı olarak tartışılan bir konu olmuştur. Öğretmenin nitelik olarak kendisinden beklenilenleri yerine getirdiği varsayıldığında, bireyin yaşama dönük anlamlı bilgiyi yapılandırdığg öğrenme öğretme sürecinin de verimli geçmesi sağlanacaktır.

Özetle, eğitim ve öğretimin bütün boyutlarıyla dinamik bir yapıya sahip olması, bu süreçte önemli bir rol üstlenen öğretmenin görevinin ve bu görevin gerektirdiği niteliklerin sürekli sorgulanmasını ve geliştirilmesini gerekli kılar. Bu nedenle Millî Eğitim Bakanlığı’nın üniversitelerle işbirliği yaparak, öğretmen yeterlikleri üzerine yürüttüğü çalışmalar süreklilik göstermektedir (MEB, 2006).

Öğretmen yeterlikleri ile ilgili Millî Eğitim Bakanlığı ve üniversitelerin işbirliği içersinde çalışmalar yapılmış olsa da öğretim elemanlarının yeterlikleri ile ilgili çalışmaların sınırlı düzeyde kaldığı söylenebilir. Özellikle son yıllarda uygulamaya konulan öğretim programlarının dayandığ1 öğrenme ve öğretme yaklaşımları açısından önemi birçok bilimsel çalışma ile ortaya konulan yaratıcı dramanın uygulayıcıları olan öğretmenlerle ilgili bazı çalışmalar yapılmış olsa da öğretim elemanlarının yeterlikleri ile olarak ilgili alanyazında yeterli çalışmanın olmadığı görülmüştür.

Bir eğitim sisteminin bir öğretmenden beklediği özelliklerin tamamı, bir yaratıcı drama eğitmeninden de beklenir (Adıgüzel, 2018). Dolayısıyla üniversitelerde okutulan yaratıcı drama derslerini vermekle sorumlu olan öğretim elemanlarının yeterlikleri ile öğretmenlerin yeterliklerinin benzer olduğu söylenebilir.

Yaratıcı drama eğitmeni, drama çalışmalarında katılımcılara rehberlik edendir. Bu alanda süreci tasarlayan, biçimlendiren, yöneten eğitmen-öğretmen kavramından yaratıcı drama süreçlerine hakim, kuramsal ve uygulamalı çalışmalarda yeterli, uygulama becerisi de olan ya da aynı süreçleri bildiği halde farklı bir alanda uzman olan, yaratıcı dramayı bir yöntem olarak kendi alanında kullanan öğretmen anlaşılmalıdır (Adıgüzel, 2018). Dolayısıyla eğitimin hangi kademesinde olursa olsun bir yaratıcı drama eğitmeninden beklenilen birtakım yeterlikler söz konusudur.

Bir yöntem, yalnızca o yöntemi kullanan kişi kadar iyidir (McCaslin, 2006/2016, s.277). Başka bir deyişle yöntemin etkililiği, yöntemin uygulayıcısı olan öğretmen ya da eğitmenlerin mesleki yeterliliği ile ilişkilidir. Yaratıcı drama öğretmeninin kişisel ve mesleki açıdan çeşitli özelliklere sahip olmaları beklenir. Kişisel özelliklerin ya da sahip olunması gereken temel değerlerin arasında; insanı sevme, sayg11ı olma, kendisine güvenme, yaratıcı düşünme, özgün olma, sabırlı davranma, farklı görüşleri dikkate alma, hızlı düşünme, karar verme, çevresine örnek olma, empati kurma, öğrenmeye istekli olma, gelişmeye açık olma, bilimsel düşünmeye saygılı olma vb. sayılabilir. Drama öğretmeninin mesleki özellikleri ise genel kültür birikimi, alan bilgisi ve drama öğretmenliği becerilerinden oluşur (Üstündağ, 2009). 
Alanyazında daha çok yöntem boyutuyla ön plana çıkan yaratıcı drama aynı zamanda kendi amaçları ve içeriği olan, belirli öğrenme kuramlarına dayanan ya da bu kuramlarla ilişkili olan, kendine özgü ölçme ve değerlendirme yaklaşımlarına sahip bağımsız bir ders olma özelliğine sahiptir (Adıgüzel, 2018). Dolaysıyla kendine özgü bir yapıya sahip olan dramanın uygulayıcısı olan öğretmenlerin, eğitmenlerin ya da öğretim elemanlarının da çeşitli yeterliklere sahip olmaları gerekir. Söz konusu bu yeterlikler hızla değişen toplum dinamiklerine bağlı olarak çeşitlenebilir ya da artabilir. Dolayısıyla farklı zaman dilimlerinde drama eğitimi verecek olan eğitimcilerden beklentiler de değişebilir.

Drama eğitmenlerinden beklentilerin ya da drama eğitmenlerinin sahip olmaları gereken özelliklerin günümüz koşullarında hangi çerçevede ve hangi noktalarda yoğunlaştığını belirlemek bu araştırmanın önemini arttırmıştır. Başka bir deyişle drama öğretmenlerinin yeterlikleri ile ilgili daha önce birtakım çalışmalar yapılmış olsa da söz konusu çalışmaların sınırlı kaldığı ve daha güncel çalışmalara ihtiyaç duyulduğu söylenebilir. Ayrıca alanyazın incelendiğinde, Kasapoğlu(2019), Çetingöz (2012), Kara (2014), Okvuran (2003) ve Tutuman (2011) tarafindan daha önce yapılan çalışmaların genellikle öğretmen ya da drama eğitimi alan bireylerin yeterliklerini belirlemekle sınırlı kaldığı görülmüştür. Ancak bu araştırmanın üniversitelerde bu alanda eğitim veren öğretim elemanlarının yeterlikleriyle ilgili olması nedeniyle özgün bir araştırma olduğu söylenebilir.

$\mathrm{Bu}$ araştırmada "Çocuk gelişimi programı öğrencilerinin görüşlerine göre çocuk ve drama dersini veren öğretim elemanlarının nitelikleri nasıl olmadır?” sorusuna yanıt aranmıştır.

\section{Araştırmanın Amacı}

$\mathrm{Bu}$ araştırmanın amacı; üniversitelerin meslek yüksekokulları bünyesinde yer alan Çocuk Gelişimi Programında öğrenim gören öğrencilerin almış oldukları çocuk ve drama dersini veren öğretim elemanlarının niteliklerine ilişkin öğrenci görüşlerini belirleyip değerlendirmektir.

\section{Yöntem}

\section{Araştırma Modeli}

$\mathrm{Bu}$ araştırma, çocuk ve drama dersi veren öğretim elemanlarının niteliklerine ilişkin Çocuk Gelişimi Programı öğrencilerinin görüşlerini belirlemek amacıyla tarama türünde nitel bir araştırmadır. Nitel araştırma, gözlem, görüşme ve doküman analizi gibi nitel veri toplama yöntemlerinin kullanıldığı, algıların ve olayların doğal ortamda gerçekçi ve bütüncül bir biçimde ortaya konmasına yönelik nitel bir sürecin izlendiği araştırma olarak tanımlanabilir (Yıldırım ve Şimşek, 2013). Tarama modelleri ise geçmişte ya da halen var olan bir durumu var olduğu şekliyle betimlemeyi amaçlayan araştırma yaklaşımlarıdır. Araştırmaya konu olan olay, birey ya da nesne, kendi koşulları içinde ve olduğu gibi tanımlanmaya çalışılır (Karasar, 2015). Araştırmanın amacına en uygun desen olması nedeniyle araştırma tarama modeline göre desenlenmiştir.

\section{Çalışma Grubu}

Araştırmanın çalışma grubunu 2018-2019 eğitim öğretim yılında üniversitelerin meslek yüksekokulları Çocuk Gelişimi Programlarında öğrenim gören, çocuk ve drama dersi alan öğrenciler oluşturmuştur. Çalışma grubuamaçl1örnekleme yöntemiyle belirlenmiştir. Amaçlıörnekleme, olasılıklı 
ve seçkisiz olmayan bir örnekleme yaklaşımı olup, çalışmanın amacına bağlı olarak bilgi açısından zengin durumların seçilerek derinlemesine araştırma yapılmasına olanak tanır (Büyüköztürk ve diğ., 2009). Araştırma kapsamında Siirt Üniversitesi’nden 16 öğrenci, Mardin Artuklu Üniversitesi’nden 13 öğrenci, Batman Üniversitesi'nden 28 öğrenci ve Şırnak Üniversitesi’nden 37 öğrenci olmak üzere toplam 94 öğrenciden görüş alınmıştır. Böylece farklı üniversitelerde aynı dersi alan ve sosyokültürel olarak benzerlik gösteren illerde öğrenim gören öğrencilerin görüşleri arasındaki benzerlik ve farklı1ıkları ortaya koymak amacıyla çalışma gurubu belirlenmiştir.

\section{Veri Toplama Araçları}

Araştırmada veri toplama aracı olarak araştırmacı tarafından hazırlanan ve bir açık uçlu sorudan oluşan görüşme formu kullanılmıştır. Görüşme formu hazırlanırken eğitim programları ve öğretimi ile yaratıcı drama alanında uzman kişilerden görüş alınmış, ardından görüşme formu 4 öğrenciye uygulanmış ve gerekli düzeltmeler yapılarak forma son şekli verilmiştir. Daha sonra çalışma grubunda yer alan öğrencilere; "Sizce drama dersi veren bir öğretim elemanının sahip olması gereken nitelikler nelerdir?” sorusu yöneltilmiştir.

\section{Verilerin Toplanması}

Araştırma kapsamında dört farklı üniversitenin Çocuk Gelişimi Programlarında öğrenim gören, çocuk ve drama dersi alan öğrencilere görüşme formu uygulanmış ve öğrencilerin görüşleri yazılı olarak alınmıştır.

\section{Verilerin Analizi}

Araştırmadan elde edilen verilere içerik analizi yapılmıştır. İçerik analizi, hacimli olan nitel materyali, temel tutarlılıkları ve anlamları belirlemeye yönelik olarak herhangi bir nitel veri indirgeme ve anlamlandırma çabası girişimi olarak tanımlanır (Patton, 2002/2014, s.453). Diğer bir ifadeyle belirli kurallara dayalı olarak kodlamalarla bir metnin bazı sözcüklerinin daha küçük içerik kategorileri ile özetlendiği sistematik, yinelenebilir bir tekniktir (Büyüköztürk ve diğ., 2009, s. 284). Söz konusu analiz sürecinde asıl amaç toplanan verileri açıklayabilecek kavramlara ve kavramlar arası ilişkilere ulaşmaktır (Yıldırım ve Şimşek, 2013, s.259). Buna göre farklı üniversitelerde öğrenim gören öğrencilerin yaratıcı drama derslerini vermekle sorumlu olan öğretim elemanlarının sahip olmaları gereken niteliklere ilişkin elde edilen veriler doğrultusunda araştırmacı tarafindan her bir üniversite için temalar ve buna bağlı alt temalar belirlenmiştir. Başka bir alan uzmanı tarafından da aynı veriler incelenmiş ve aynı şekilde temalar ve buna bağlı alt temalar belirlenmiştir. Bunun sonucunda öğretim elemanlarının niteliğine ilişkin olarak kişisel ve mesleki nitelikler olmak üzere iki tema belirlenmiş ve alt temalar bu başlıklar altında toplanmıştır. Temaların belirlenmesi sürecinde görüş birliği ve görüş ayrılığ verilmiştir. Bu süreçte görüş birliği ve görüş ayrılı̆̆ 1 yaşanan konularda iki araştırmacı arasındaki tutarlılığın hesaplanmasında Miles ve Huberman'ın (1994) görüş birliği formülü [P=(görüş birliği/ görüş birliği+görüş ayrılı̆̆ı)x100] kullanılmıştır. Bunun sonucunda iki araştırmacı arasındaki görüş birliğine ilişkin güvenirlik katsayısı \%79.3 olarak bulunmuştur. Miles ve Huberman (1994)'a göre kodlayıcılar arasındaki güvenirlik katsayısı \%70'in üzerindeki değerler ölçüt alındığından elde edilen katsayıya göre araştırma verilerinin güvenilir olduğu kabul edilmiştir. 


\section{Bulgular}

Bu bölümde Batman, Mardin Artuklu, Siirt ve Şırnak Üniversitelerinin Çocuk Gelişimi Programında öğrenim gören öğrencilerin Çocuk ve Drama dersini veren öğretim elemanlarının niteliklerine ilişkin öğrenci görüşleri her bir üniversite açısından ayrı ayrı ele alınmış, daha sonra dört farklı üniversitede öğrenim gören öğrencilerin öğretim elemanlarının niteliklerine ilişkin belirttikleri ortak ifadelere yer verilmiştir. Araştırma bulguları bu alt başlıklar altında sunulmuştur.

Araştırma kapsamında, Batman Üniversitesi Çocuk Gelişimi Programında öğrenim gören öğrencilerin çocuk ve drama dersini veren öğretim elemanlarının niteliklerine ilişkin görüşleri Tablo 1 'de verilmiştir.

Tablo 1. Batman Üniversitesi’nde Öğrenim Gören Öğrencilerin Öğretim Elemanlarının Niteliklerine Illişkin Görüşleri

\begin{tabular}{|c|c|c|c|}
\hline Temalar & Alt Temalar & f & $\%$ \\
\hline \multirow{9}{*}{ Kişisel Nitelikler } & Eğlenceli bir kişiliğe sahip olmalı & 5 & 18 \\
\hline & Kriz yönetimi iyi olmalı & 4 & 14 \\
\hline & Farklı görüşlere saygı duymalı & 3 & 11 \\
\hline & Uyumlu olmalı & 2 & 7 \\
\hline & Özverili olmalı & 1 & 4 \\
\hline & İnisiyatif alabilmeli & 1 & 4 \\
\hline & Kapsamlı düşünebilmeli & 1 & 4 \\
\hline & Duygu kontrolünü sağlayabilmeli & 1 & 4 \\
\hline & Farkındalık seviyesi yüksek olmalı & 1 & 4 \\
\hline \multirow{14}{*}{$\begin{array}{l}\text { Mesleki } \\
\text { Nitelikler }\end{array}$} & Yol gösterici olmalı & 4 & 14 \\
\hline & Drama sürecini iyi plânlamalı & 4 & 14 \\
\hline & Yorum yapabilmeli & 3 & 11 \\
\hline & Öğrencilerin ilgi ve isteklerine dikkat etmeli & 3 & 11 \\
\hline & Zamanında dönüt vermeli & 3 & 11 \\
\hline & Grubun gelişim özelliklerini iyi bilmeli & 3 & 11 \\
\hline & Tekrardan kaçınmalı & 2 & 7 \\
\hline & Motive edici olmalı & 2 & 7 \\
\hline & Evrensel konulara da yer vermeli & 1 & 4 \\
\hline & Soru sorma yeteneği olmalı & 1 & 4 \\
\hline & Analiz becerisi yüksek olmalı & 1 & 4 \\
\hline & Günceli takip etmeli & 1 & 4 \\
\hline & Dramayı sevdirebilmeli & 1 & 4 \\
\hline & Yönergeleri açık olmalı & 1 & 4 \\
\hline
\end{tabular}

Tablo 1 incelendiğinde, Batman Üniversitesi’nde öğrenim gören öğrenciler öğretim elemanlarının niteliklerini; eğlenceli bir kişiliğe sahip ( $f=5)$, kriz yönetimi iyi olan $(f=4)$, yol gösterici olan $(\mathrm{f}=4)$, drama sürecini iyi planlayabilen $(\mathrm{f}=4)$, yorum yapabilen $(\mathrm{f}=3)$, farklı görüşlere sayg1 duyabilen ( $\mathrm{f}=3$ ), öğrencilerin ilgi ve isteklerine dikkat eden ( $\mathrm{f}=3)$, zamanında dönüt veren $(\mathrm{f}=3)$, grubun gelişim özelliklerini iyi bilen $(\mathrm{f}=3$ ) olarak belirtmişlerdir. Bunun yanı sıra öğrencilerin daha az vurguladıkları nitelikler ise günceli takip eden ( $\mathrm{f}=1)$, dramayı sevdirebilen $(\mathrm{f}=1)$, farkındalık 
seviyesi yüksek olan ( $\mathrm{f}=1)$ ve yönergeleri açık olan $(\mathrm{f}=1)$ gibi niteliklerin ise öğrenciler tarafindan daha az belirtilen nitelikler olduğu görülmüştür. Öğrencilerin söz konusu nitelikler arasında tema olarak daha çok mesleki nitelikleri vurguladıkları görülmüştür. Aşağıda temalara ilişkin araştırma sürecinde elde edilen görüşmelerden bazı alıntılara yer verilmiştir.

Ö̆̆r. 14: "Bana göre drama dersini verecek olan birinin eğlenceli bir kişiliğe sahip olmast gerekir yoksa ders işlenmez."

Öğr. 7: "Ders sırasında rol gereği bazı sorunları çözüme kavuşturmak gerekir bunun için daima sorun çözebilme yeteneği olmall."

Öğr. 13: "Her ders gibi bunda da hocanın planlı olması lazım."

Öğr. 1: "Bir konu ile ilgili herkes konuşabilmeli, fikirlerini açıkça söyleme cesareti olmalı ama ögrretim elemanının da farklı görüşlere açılk olmalı ki söyleyebilsin."

Araştırma kapsamında, Mardin Artuklu Üniversitesi Çocuk Gelişimi Programında öğrenim gören öğrencilerin çocuk ve drama dersini veren öğretim elemanlarının niteliklerine ilişkin görüşleri Tablo 2'de verilmiştir.

Tablo 2. Mardin Artuklu Üniversitesi’nde Öğrenim Gören Öğrencilerin Öğretim Elemanlarının Niteliklerine İlişkin Görüşleri

\begin{tabular}{|c|c|c|c|}
\hline Temalar & Alt Temalar & f & $\%$ \\
\hline \multirow{10}{*}{ Kişisel Nitelikler } & Yeniliğe açık olmalı & 5 & 38 \\
\hline & Farklı görüşlere saygı duymalı & 5 & 38 \\
\hline & Sevecen olmalı & 3 & 23 \\
\hline & Mesleğini seven & 3 & 23 \\
\hline & Empati kurabilmeli & 2 & 15 \\
\hline & Rol model olmalı & 2 & 15 \\
\hline & Eleştiriye açık olmalı & 2 & 15 \\
\hline & Farklı düşünmeye sevk etmeli & 2 & 15 \\
\hline & Güvenilir olmalı & 1 & 8 \\
\hline & Mizah yeteneği iyi olmalı & 1 & 8 \\
\hline \multirow{9}{*}{$\begin{array}{l}\text { Mesleki } \\
\text { Nitelikler }\end{array}$} & Yol gösterici olmalı & 3 & 23 \\
\hline & Araştırma/Sorgulama yeteneği olmalı & 3 & 23 \\
\hline & Materyal ve kostüm bilgisine sahip olan & 3 & 23 \\
\hline & Öğrencileri aktif kılabilmeli & 2 & 15 \\
\hline & Yetenekleri keşfedebilmeli & 2 & 15 \\
\hline & Uygulama bilgisi olmalı & 1 & 8 \\
\hline & Zamanında dönüt vermeli & 1 & 8 \\
\hline & Özel eğitim bilgisine sahip olmalı & 1 & 8 \\
\hline & Günceli takip etmeli & 1 & 8 \\
\hline
\end{tabular}

Tablo 2 incelendiğinde, Mardin Artuklu Üniversitesi’nde öğrenim gören öğrenciler öğretim elemanlarının niteliklerini; yeniliğe açık olan ( $f=5)$, farklı görüşlere saygı duyan ( $f=5)$, sevecen $(f=3)$, yol gösteren $(f=3)$, araştırma/sorgulama yeteneği olan $(f=3)$, mesleğini seven $(f=3)$, materyal ve kostüm bilgisine sahip olan ( $\mathrm{f}=3$ ) olarak belirtmişlerdir. Bunun yanı sıra uygulama bilgisi olan 
$(\mathrm{f}=1)$, güvenilir ( $\mathrm{f}=1$ ), zamanında dönüt veren ( $\mathrm{f}=1$ ), özel eğitim bilgisine sahip ( $\mathrm{f}=1$ ), günceli takip eden $(\mathrm{f}=1)$, mizah yeteneği olan $(\mathrm{f}=1)$ gibi niteliklerin ise öğrenciler tarafından daha az belirtilen nitelikler olduğu görülmüştür. Öğrencilerin söz konusu nitelikler arasında tema olarak daha çok kişisel nitelikleri vurguladıkları görülmüştür. Aşağıda temalara ilişkin araştırma sürecinde elde edilen görüşmelerden bazı alıntılara yer verilmiştir.

Öğr. 10: "Öğretim elemanı yenilikler açık olmalı ve bu yenilikleri paylaşmayı bilmelidir."

Öğr. 8: "Yeni fikirlere, farklı durumlara açık olmalı ve buna karşı saygılı olmalıdır. Yoksa dersi tek başına işlemek durumunda kalabilir."

Ö̆̆r. 5: "Mesleğinde sevecen olmalı ve bu durumu öğrencilerine yansitmalıdır ki derse karşı ilgi artsin."

Öğr. 12: "Araştırarak kendini sürekli geliştirebilme yeteneği iyi olmall aksi takdirde kendini sürekli tekrar eder ve eski bilgilerle ders işler. Bu da derse olan ilgimizi azaltır."

Araştırma kapsamında, Siirt Üniversitesi Çocuk Gelişimi Programında öğrenim gören öğrencilerin çocuk ve drama dersini veren öğretim elemanlarının niteliklerine ilişkin görüşleri Tablo 3'te verilmiştir.

Tablo 3. Siirt Üniversitesi’nde Öğrenim Gören Öğrencilerin Öğretim Elemanlarının Niteliklerine Illişkin Görüşleri

\begin{tabular}{|c|c|c|c|}
\hline Temalar & Alt Temalar & $\mathbf{f}$ & $\%$ \\
\hline \multirow{16}{*}{ Kişisel Nitelikler } & Empati kurabilmeli & 9 & 56 \\
\hline & Gelişmeye açık olmalı & 6 & 38 \\
\hline & Tutarlı olmalı & 4 & 25 \\
\hline & Hoşgörülü olmalı & 4 & 25 \\
\hline & Çocuk ruhlu olmalı & 3 & 19 \\
\hline & Eleştiriye açık olmalı & 3 & 19 \\
\hline & Kriz yönetimi iyi olmalı & 3 & 19 \\
\hline & Eleştirel düşünebilmeli & 2 & 13 \\
\hline & İdealist olmalı & 2 & 13 \\
\hline & Özgün olmalı & 2 & 13 \\
\hline & Mesleğine karşı saygılı olmalı & 2 & 13 \\
\hline & Farklılıkları iyi yönetmeli & 2 & 13 \\
\hline & Duygu ve düşünceleri özgürce paylaşmalı & 2 & 13 \\
\hline & Arkadaşlık ilişkileri gelişmiş olmalı & 1 & 6 \\
\hline & Sosyal ilişkileri gelişmiş olmalı & 1 & 6 \\
\hline & Hizlı karar alabilmeli & 1 & 6 \\
\hline \multirow{8}{*}{ Mesleki Nitelikler } & Drama sürecini iyi planlamalı & 7 & 44 \\
\hline & Yetenekleri keşfedebilmeli & 3 & 19 \\
\hline & Yapıcı eleştirmeli & 2 & 13 \\
\hline & Yönergeleri açık olmalı & 2 & 13 \\
\hline & Zamanı iyi kullanmalı & 2 & 13 \\
\hline & Merak duygusunu uyandırabilmeli & 1 & 6 \\
\hline & Drama ile hayatı bütünleştirmeli & 1 & 6 \\
\hline & Sözcük daracığı geniş olmalı & 1 & 6 \\
\hline
\end{tabular}


Tablo 3 incelendiğinde, Siirt Üniversitesi'nde öğrenim gören öğrenciler öğretim elemanlarının niteliklerini; empati kurabilen $(f=9)$, drama sürecini iyi planlayan $(f=7)$, gelişmeye açık olan ( $\mathrm{f}=6)$, tutarlı olan $(\mathrm{f}=4)$, hoşgörülü $(\mathrm{f}=4)$, yetenekleri keşfedebilen $(\mathrm{f}=3)$, çocuk ruhlu $(\mathrm{f}=3)$, eleştiriye açık olan $(\mathrm{f}=3)$ ve kriz yönetebilen $(\mathrm{f}=3)$ olarak belirtmişlerdir. Bunun yanı sıra merak duygusunu uyandırabilen ( $\mathrm{f}=1$ ), drama ile hayatı bütünleştirebilen ( $\mathrm{f}=1)$, sözcük daracı $\breve{g} 1$ geniş (1), arkadaşlık ilişkileri ( $\mathrm{f}=1$ ) ve sosyal ilişkileri gelişmiş $(\mathrm{f}=1)$ ve hızlı karar alabilen $(\mathrm{f}=1)$ gibi niteliklerin ise öğrenciler tarafından daha az belirtilen nitelikler olduğu görülmüştür. Öğrencilerin söz konusu nitelikler arasında tema olarak daha çok kişisel nitelikleri vurguladıkları görülmüştür. Aşağıda temalara ilişkin araştırma sürecinde elde edilen görüşmelerden bazı alıntılara yer verilmiştir.

Öğr. 13: "Bir hoca öğrencileriyle arkadaş gibi olmalı onlarla empati kurabilmelidir."

Öğr. 9: "Önceden drama dersi ile ilgili bir planının olması lazım bence. Planlı olmadiğ zaman bazen ne yapacağını hoca da biz de düşünmek durumunda kalabiliriz."

Öğr. 7: "Ĕ̆itimde çokyeni fikirler ortaya çımaktadır bununla birlikte yeni teknolojik araçlar ve modeller gelişstiriliyor. Bunları öğrenmek için öğretim elemanı gelişmelere açık olmall."

Öğr. 2: "Özellikle drama dersi çok yönlü bir derstir ve kapsamı da bir o kadar geniştir. Bunun için ders işlerken hocanın bir dediği diğerini tutmalı aksi takdirde öğrenci bazı konuları anlamakta zorlanabilir."

Araştırma kapsamında, Şırnak Üniversitesi Çocuk Gelişimi Programında öğrenim gören öğrencilerin çocuk ve drama dersini veren öğretim elemanlarının niteliklerine ilişkin görüşleri Tablo 4'te verilmiştir.

Tablo 4. Şırnak Üniversitesi’nde Öğrenim Gören Öğrencilerin Öğretim Elemanlarının Niteliklerine Ilişkin Görüşleri

\begin{tabular}{|c|c|c|c|}
\hline Temalar & Alt Temalar & f & $\%$ \\
\hline \multirow{12}{*}{$\begin{array}{l}\text { Kişisel } \\
\text { Nitelikler }\end{array}$} & Empati kurabilmeli & 7 & 19 \\
\hline & Eleştiriye açık olmalı & 7 & 19 \\
\hline & Eğlenerek ders işlemeli & 5 & 14 \\
\hline & Pratik düşünebilmeli & 3 & 8 \\
\hline & Liderlik özellikleri olmalı & 3 & 8 \\
\hline & Güler yüzlü olmalı & 3 & 8 \\
\hline & Samimi ve içten olmalı & 2 & 5 \\
\hline & Rol model olmalı & 2 & 5 \\
\hline & Meraklı olmalı & 1 & 3 \\
\hline & Çözüm üretebilmeli & 1 & 3 \\
\hline & Yapıcı olmalı & 1 & 3 \\
\hline & Paylaşmayı sevmeli & 1 & 3 \\
\hline
\end{tabular}


Tablo 4. Şırnak Üniversitesi’nde Öğrenim Gören Öğrencilerin Öğretim Elemanlarının Niteliklerine Ilişkin Görüşleri (Devamı)

\begin{tabular}{llcc}
\hline Temalar & Alt Temalar & f & \% \\
\hline & Grubun gelişim özelliklerini iyi bilmeli & 10 & 27 \\
& Öğrencileri aktif kılabilmeli & 9 & 24 \\
& İyi bir dinleyici olmalı & 7 & 19 \\
& Motive edici olmalı & 7 & 19 \\
& Teori ve uygulamayı birlikte işlemeli & 4 & 11 \\
& Genel kültür bilgisi iyi olmalı & 2 & 5 \\
Nitelikler & Drama sürecini iyi planlamalı & 2 & 5 \\
& Uygulama bilgisi olmalı & 1 & 3 \\
& Öğrenciler arasında etkileşimi sağlayabilmeli & 1 & 3 \\
& Deneyimli olmalı & 1 & 3 \\
& Müzik bilgisi olmalı & 1 & 3 \\
& Sinıf yönetimi konusunda yetkin olmalı & 1 & 3 \\
& Öğrenme psikolojisi bilgisine sahip olmalı & 1 & 3 \\
& Kitap okumayı sevmeli & 1 & 3 \\
& Materyal ve kostüm bilgisine sahip olmalı & 1 & 3 \\
& Teknoloji ile ilgili bilgi sahibi olmalı & 1 & 3 \\
& Farkındalık seviyesi yüksek olmalı & 1 & 3 \\
\hline
\end{tabular}

Tablo 4 incelendiğinde, Şırnak Üniversitesi’nde öğrenim gören öğrenciler öğretim elemanlarının niteliklerini; grubun gelişim özelliklerini iyi bilen ( $\mathrm{f}=10)$, öğrencileri aktif kılan ( $\mathrm{f}=9$ ) aynı zamanda iyi bir dinleyici olan ( $\mathrm{f}=7$ ), öğrencilerini motive edebilen ( $\mathrm{f}=7$ ), empati kurabilen $(\mathrm{f}=7)$, eleştiriye açık $(\mathrm{f}=7)$ ve eğlenerek ders işleyen $(\mathrm{f}=5)$ olarak belirtmişlerdir. Bunun yanı sıra kitap okumayı seven ( $\mathrm{f}=1$ ), materyal ve kostüm bilgisine sahip ( $\mathrm{f}=1)$, teknoloji ile ilgili bilgi sahibi olan ( $\mathrm{f}=1)$, yapıcı $(\mathrm{f}=1)$, paylaşmayı seven $(\mathrm{f}=1)$ ve farkındalık seviyesi yüksek $(\mathrm{f}=1)$ gibi niteliklerin ise öğrenciler tarafından daha az belirtilen nitelikler olduğu görülmüştür. Öğrencilerin söz konusu nitelikler arasında tema olarak daha çok mesleki nitelikleri vurguladıkları görülmüştür. Aşağıda temalara ilişkin araştırma sürecinde elde edilen görüşmelerden bazı alıntılara yer verilmiştir.

Öğr. 19: "Bir drama eğitmeni ya da öğretmeni ögrencilerin ilgi ve ihtiyaçlarına göre ders işleyebilmelidir. Bunu yapabilmesi için öğrencilerin her yönden gelişim özelliklerini iyi tanımalı ve buna göre ders işlemelidir."

Öğr. 8: "Drama hocası bütün ögrencilerin yapılan etkinliklere katılımını sağlamalıdır. Bu da dersin daha verimli geçmesini să̆lar."

Öğr. 24: "İyi bir dinleyici olmalıdır. Öğrencilerin konu ile alakalı ve alakasız görüşlerini etkin bir şekilde dinlemeli ve es geçmemelidir."

Öğr. 32: "Motivasyon gücü yüksek olmalı ve bunu öğrencilerine yansitabilmelidir."

Araştırma kapsamında, Batman, Mardin Artuklu, Siirt ve Şırnak Üniversitelerinin Çocuk Gelişimi Programında öğrenim gören öğrencilerin çocuk ve drama dersini veren öğretim elemanlarının niteliklerine ilişkin ortak görüşleri Tablo 5 'te verilmiştir. 
Tablo 5. Batman, Mardin Artuklu, Siirt ve Şırnak Üniversitelerinde Öğrenim Gören Ögrrencilerin Öğretim Elemanlarının Niteliklerine Iliş̧kin Ortak Görüşleri

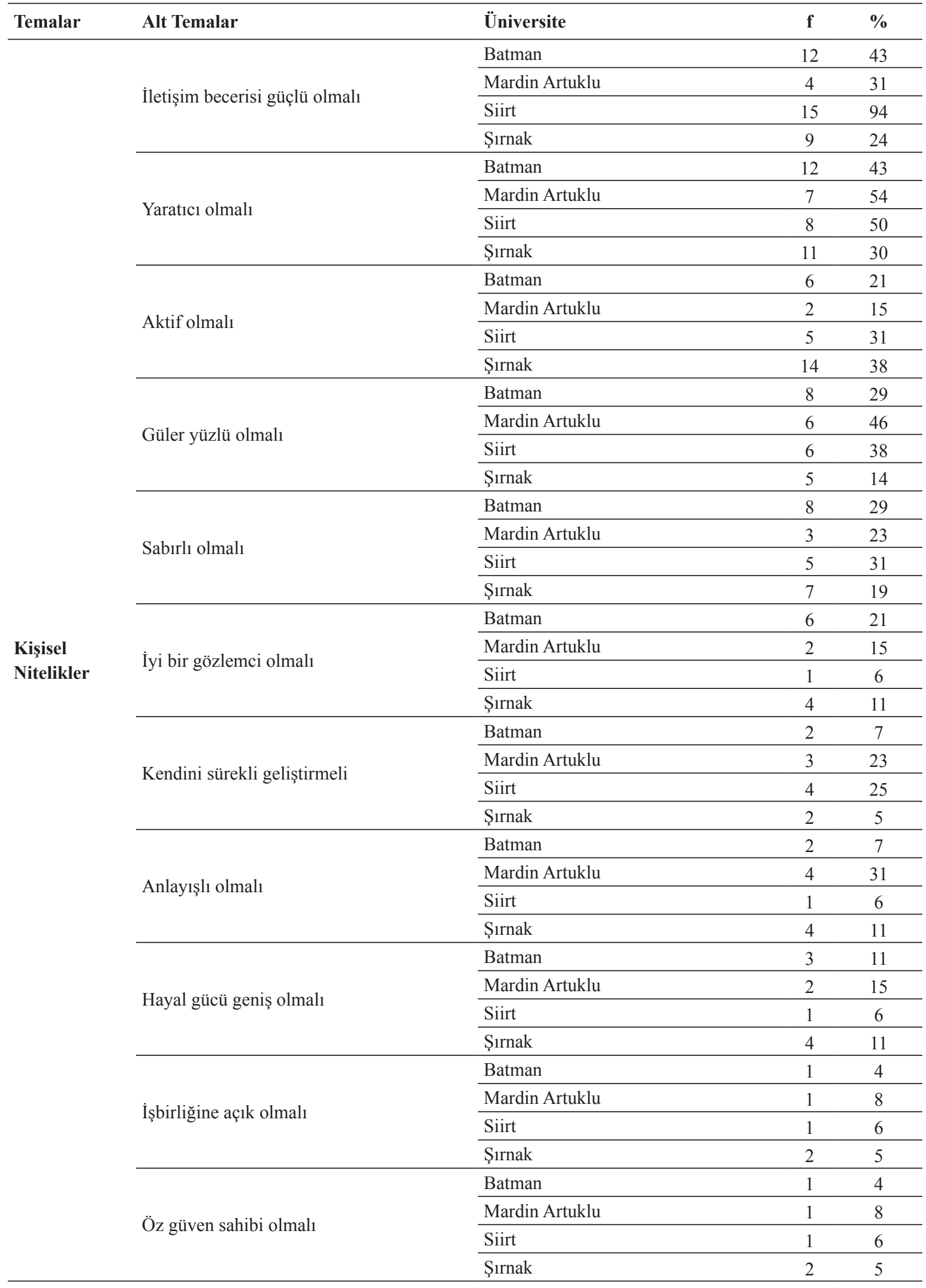


Tablo 5. Batman, Mardin Artuklu, Siirt ve Şırnak Üniversitelerinde Öğrenim Gören Öğrencilerin Öğretim Elemanlarının Niteliklerine İlişkin Ortak Görüşleri (Devamı)

\begin{tabular}{|c|c|c|c|c|}
\hline Temalar & Alt Temalar & Üniversite & f & $\%$ \\
\hline \multirow{20}{*}{$\begin{array}{l}\text { Mesleki } \\
\text { Nitelikler }\end{array}$} & \multirow{4}{*}{ Alan bilgisine sahip olmalı } & Batman & 18 & 64 \\
\hline & & Mardin Artuklu & 4 & 31 \\
\hline & & Siirt & 6 & 38 \\
\hline & & Şırnak & 7 & 19 \\
\hline & \multirow{4}{*}{ Yöntem ve teknik bilgisi iyi olmalı } & Batman & 6 & 21 \\
\hline & & Mardin Artuklu & 9 & 69 \\
\hline & & Siirt & 7 & 44 \\
\hline & & Şırnak & 10 & 27 \\
\hline & \multirow{4}{*}{ Oyun bilgisi olmalı } & Batman & 6 & 21 \\
\hline & & Mardin Artuklu & 1 & 8 \\
\hline & & Siirt & 6 & 38 \\
\hline & & Şırnak & 6 & 16 \\
\hline & \multirow{4}{*}{ Beden dilini iyi kullanabilmeli } & Batman & 1 & 4 \\
\hline & & Mardin Artuklu & 7 & 54 \\
\hline & & Siirt & 7 & 44 \\
\hline & & Şırnak & 1 & 3 \\
\hline & \multirow{4}{*}{ Doğaçlama yeteneğine sahip olmalı } & Batman & 1 & 4 \\
\hline & & Mardin Artuklu & 2 & 15 \\
\hline & & Siirt & 9 & 56 \\
\hline & & Şırnak & 1 & 3 \\
\hline
\end{tabular}

Tablo 5 incelendiğinde, Batman, Mardin Artuklu, Siirt ve Şırnak Üniversitelerinde öğrenim gören öğrenciler öğretim elemanlarının niteliklerini; iletişim becerisi güçlü olan ( $\mathrm{f}=40)$, yaratıcı ( $\mathrm{f}=38$ ), alan bilgisine sahip ( $\mathrm{f}=35$ ), yöntem ve teknik bilgisi iyi olan ( $\mathrm{f}=32$ ), aktif olan (27), güler yüzlü (25), sabırlı ( $f=23$ ), oyun bilgisine sahip ( $f=19)$, beden dilini iyi kullanabilen ( $f=16$ ) ve doğaçlama yeteneğine sahip ( $\mathrm{f}=13$ ) olarak belirtmişlerdir. Bunun yanı sıra işbirliğine açı $(\mathrm{f}=5)$ ve öz güven sahibi ( $\mathrm{f}=5)$ gibi niteliklerin ise öğrenciler tarafindan daha az belirtilen nitelikler olduğu görülmüştür. Dört farkl1 üniversitede öğrenim gören öğrencilerin söz konusu nitelikler arasında ortak tema olarak daha çok kişisel nitelikleri vurguladıkları görülmüştür. Aşağıda araştırma kapsamında yer alan dört farklı üniversitede öğrenim gören öğrencilerin temalara ilişkin araştırma sürecinde elde edilen görüşmelerden bazı alıntılara yer verilmiştir.

Öğr. 2 (Mardin Artuklu Ü.): "Ögrrencilere dersi o kadar güzel ve akıcı anlatmalı ki hem ögrencinin dersi daha kolay anlamasını sağlayabilmeli hem de ögrencinin ilerde iyi bir drama eğitmeni olacağl ihtimalini göz önünde bulundurarak anlatmall."

$\ddot{O} \breve{g r} .11$ (Batman Ü.): "Aslında tüm dersler için geçerli ama drama dersini verecek olan birinin açık ve net konuşmall yani iletişim açısından bir eksiğinin olmaması gerekir."

Öğr. 23 (Şırnak $\ddot{U}$.): “Öncelikle güler yüzlü olmasını isterim ki ders daha eğlenceli ve verimli geçsin."

Öğr. 5 (Siirt Ü.): "Farkl oyunlar bilmeli bence, çünkü derste oyuna çok gerek duyuyoruz." 
Çocuk ve Drama Dersi Veren Öğretim Elemanlarının Niteliklerine İlişkin

Çocuk Gelişimi Programı Öğrencilerinin Görüşleri

\section{Tartışma, Sonuç ve Öneriler}

Araştırma kapsamında üniversitelerin meslek yüksekokulları bünyesinde yer alan Çocuk Gelişimi Programında öğrenim gören öğrencilerin almış oldukları çocuk ve drama dersini veren öğretim elemanlarının niteliklerine ilişkin öğrenci görüşlerini Batman, Mardin Artuklu, Siirt ve Şırnak Üniversiteleri açısından değerlendirilmiştir. Bu amaçla öğrencilerin "Sizce Çocuk ve Drama dersi veren bir öğretim elemanının sahip olması gereken nitelikler nelerdir?” sorusuna ilişkin yanıtları değerlendirilmiştir. Yanıtlar her bir üniversite için ayrı ayrı ele alınmış daha sonra dört üniversitede ögrenim gören öğrencilerin araştırma sorusuna ilişkin ortak görüşlerine yer verilmiştir.

Batman Üniversitesi Çocuk Gelişimi Programında öğrenim gören öğrencilerin çocuk ve drama dersini veren öğretim elemanlarının niteliklerine ilişkin görüşleri incelendiğinde; öğretim elemanının eğlenceli bir kişiliğe sahip olması gerektiği en yüksek frekans değerine sahip nitelik olmuştur. Nitekim Kasapoğlu (2019) tarafindan yapılmış benzer bir çalışmada da yaratıcı drama liderinin kişisel özelliklerine ilişkin katılımcıların en çok vurguladıkları kavram "eğlenceli" kavramı olmuştur. Bu açıdan iki farklı araştırmanın sonuçlarının birbirini destekler nitelikte olduğu söylenebilir. Bunun yanı sıra öğrencilerin en çok vurguladıkları nitelikler; öğretim elemanının kriz yönetimi konusunda iyi olması, yol gösterici başka bir ifadeyle rehber olması ve drama sürecini de iyi planlaması gerektiğidir. Aynı şekilde Millî Eğitim Bakanlığı Öğretmen Yetiştirme ve Eğitimi Genel Müdürlüğü tarafından belirlenen Öğretmenlik Mesleği Genel Yeterlikleri kapsamında belirlenen alt yeterlik alanlarından biri de öğrenciye rehberlik etmektir (MEB, 2006). Bu yönüyle de drama dersini veren bir öğretim elemanının sahip olması gereken nitelikler ile bir öğretmenin sahip olması gereken yeterlikler arasında ortak yeterlik alanlarının olduğu söylenebilir. Bunun yanı sıra aynı üniversitede öğrenim gören öğrencilerin en az vurguladıkları nitelikler arasında ise; dramayı sevdirebilme, farkındalık seviyesi yüksek olma ve yönergeleri açık olma gibi nitelikler yer almıştır. Genel olarak Batman Üniversitesinde öğrenim gören öğrencilerin, öğretim elemanın daha çok mesleki gelişim alanına ilişkin nitelikleri vurguladıkları görülmüştür.

Mardin Artuklu Üniversitesi Çocuk Gelişimi Programında öğrenim gören öğrencilerin çocuk ve drama dersini veren öğretim elemanlarının niteliklerine ilişkin görüşleri incelendiğinde; yeniliğe açık olma, farklı görüşlere saygı duyma, sevecen olma ve yol gösterici olma gibi nitelikleri öğrencilerin daha çok vurguladıkları görülmüştür. Buradan yola çıkarak drama dersini veren bir öğretim elemanının farklı görüşlere saygı duyabilme niteliğine sahip olması önemli bir unsurdur. Ancak bunun tam anlamıyla gerçekleşebilmesi için Keleşoğlu ve Metinnam'ın (2018) belirttiği gibi yaratıcı drama eğitimi alan ve veren kişilerin sosyal adalet tutumlarının yüksek olması beklenir. Yaratıcı drama, sürekli gelişen ve her geçen gün özellikle eğitimdeki önemi ile ön plana çıkan bir alandır. Dolayısıyla bu alanda eğitim verenler hangi eğitim kademesinde olurlarsa olsunlar yenliklere açık olmalıdırlar. Aksi durumda bu alanda ders verenler ya da bir yöntem olarak yaratıcı dramadan yararlanan eğitimciler, kendilerini sürekli tekrar eden kısır döngüsel bir sürecin içinde bulabilirler. Nitekim Okvuran (2003) "Drama Öğretmeninin Yeterlikleri” isimli çalışmasında öğretmenin alanla ilgili yenilikleri izleyebilmeleri gerektiğine vurgu yapmıştır. Bunun yanı sıra aynı üniversitede öğrenim gören öğrencilerin en az belirtikleri nitelikler ise; öğretim elemanının zamanında dönüt vermesi, özel eğitim bilgisine sahip olması, günceli takip etmesi ve mizah yeteneğinin olması gerektiğidir. Bunun da öğrencilerin yaratıcı drama dersini veren öğretim elemanlarından beklentilerinin çok yönlü olduğunu göstermesi açısından önemli bulgular olduğu söylenebilir. Mardin Artuklu Üniversitesi’nde öğrenim 
gören öğrencilerin öğretim elemanının niteliklerine ilişkin genel olarak kişisel nitelikleri sıklıkla belirtikleri görülmüştür.

Siirt Üniversitesi Çocuk Gelişimi Programında öğrenim gören öğrencilerin çocuk ve drama dersini veren öğretim elemanlarının niteliklerine ilişkin görüşleri incelendiğinde; empati kurabilme, drama sürecini iyi planlama, gelişmeye açık olma, tutarlı olma, hoşgörülü olma, çalıştığı grupta var olan yetenekleri keşfedebilme, çocuk ruhlu olma, eleştiriye açık olma ve kriz yönetimi konusunda iyi olma gibi nitelikler daha çok vurgulanmıştır. Vurgulanan temel nitelikler ele alındığında; Siirt Üniversitesi'nde öğrenim gören öğrencilerin bir öğreticiden beklenenlerin yanı sıra duyuşsal alanda bazı niteliklere de değindikleri görülmüştür. Öğrenciler bu durumu, mekanik bir öğretici yerine öğrencisiyle arasında güçlü bir bağ olması gereken, hoşgörülü, empati kurabilen ve çocuk ruhlu olan gibi niteliklerle belirtmişlerdir. Ören (2008) yaratıcılığı desteklemek için gerekli öğretmen özelliklerini sıralarken; hoşgörülü olmanın yanı sıra çocuklara karşı sıcak ve ilgili olma, çocukları sevme ve çocuklara değer verdiğini hissettirme gibi özellikleri belirtmiştir. Bu yönüyle çalışma sonucunda elde edilen nitelikler ile öğretmenlerin sahip olması gereken özelliklerin duyuşsal alan açısından benzerlik gösterdiği söylenebilir. Genel olarak bakıldığında; Siirt Üniversitesi'nde öğrenim gören öğrencilerin öğretim elemanının niteliklerine ilişkin olarak kişisel nitelikleri daha çok vurguladıkları görülmüştür.

Şırnak Üniversitesi Çocuk Gelişimi Programında öğrenim gören öğrencilerin çocuk ve drama dersini veren öğretim elemanlarının niteliklerine ilişkin görüşleri incelendiğinde; grubun gelişim özelliklerini bilme, öğrencileri aktif kılabilme, iyi bir dinleyici olma, motive edici olma, empati kurabilme, eleştiriye açık olma, eğlenerek ders işleme, teori ve uygulamayı birlikte işleme gibi niteliklerin ön plana çıktığı görülmüştür. Öğrenciler tarafından sıklıkla belirtilen niteliklerden özellikle grubun gelişim özelliklerini bilme, öğrenme öğretme sürecinde öğretmenlerin göz önünde bulundurmaları gerekentemel konulardan biridir. Öğretmenin bu durumu gözardı ettiği varsayıldığında ders sürecinin tamamının ve özellikle süreçte uygulanan etkinliklerin amacına ulaşmasında önemli sorunlar ortaya çıabilir. Bu nedenle eğitimin hangi kademesinde olursa olsun öğrencilerin gelişim özelliklerinin bilinmesi öğretmenlerden beklenen bir niteliktir. Bir diğer vurgulanan önemli nitelik ise öğrencilerin aktif kılınmasıdır. Eğitimde çağdaş yönelimler doğrultusunda ortaya çıkan yaklaşımlar, modeller, yöntem ya da teknikler çoğunlukla öğrenciyi süreçte merkeze alan, başka bir deyişle öğrenme öğretme sürecinde bilginin yapılandırılması konusunda öğrenciyi sürecin öznesi yapan yaklaşımlardır. $\mathrm{Bu}$ açıdan değerlendirildiğinde eğitimde ortaya çıkan yeni yönelimlerin temel varsayımı ile çalışmadan elde edilen bazı sonuçların örtüştüğü söylenebilir. Ayrıca Başbuğ ve Adıgüzel (2019) tarafından yapılan bir çalışmada yaratıcı dramanın içinde barındırdığı teknikler aracılığıyla; öğrenmeyi keyifli hale getirdiği, empati becerisini geliştirdiği, etik ve estetik değerlerin gelişmesinde önemli katkılar sağladığı vurgulanmıştır. Bu yönüyle Şırnak Üniversitesi öğrencilerinin öğretim elemanlarına ilişkin belirttikleri niteliklerin bazılarının bu çalışma ile benzerlik gösterdiği söylenebilir. Genel olarak değerlendirildiğinde; Şırnak Üniversitesi’nde öğrenim gören öğrencilerin öğretim elemanının niteliklerine ilişkin olarak sıklıkla mesleki nitelikleri vurguladıkları görülmüştür.

Araştırmada dört farklı üniversitenin birbirinden farklılaşan öğrenci görüşleri ayrı ayrı verilirken, dört üniversitede öğrenim gören öğrencilerin öğretim elemanlarının sahip olması gereken nitelikler konusunda ortak görüş bildirdikleri nitelikler ayrıca belirtilmiştir. 
Buna göre Batman, Mardin Artuklu, Siirt ve Şırnak Üniversitelerinin Çocuk Gelişimi Programında öğrenim gören öğrencilerin çocuk ve drama dersini veren öğretim elemanlarının niteliklerine ilişkin ortak görüşleri incelendiğinde; iletişim becerilerinin güçlü, yaratıcı, alan bilgisine sahip, yöntem ve teknik bilgisi iyi düzeyde, aktif olma, güler yüzlü, sabırl1, oyun bilgisine sahip, beden dilini iyi kullanabilenin yanı sıra doğaçlama yeteneğine sahip gibi nitelikler vurgulanmıştır. Dört üniversitede öğrenim gören öğrencilerin en çok vurguladıkları niteliklerin başında; iletişim becerisi gelmektedir. Bu açıdan değerlendirildiğinde iletişim becerisinin hemen hemen her meslekte olması gereken temel bir nitelik olduğu, ancak yaratıcı drama açısından söz konusu niteliğin öneminin daha çok ön plana çıktığı söylenebilir. Adıgüzel (2018) yaratıcı dramanın genel amaçlarını açıklarken söz konusu amaçlarından birini katılımıının çeşitli iletişim becerilerini geliştirmek olarak belirtmiştir. Dolayısıyla bu sürecin verimli ve etkili bir şekilde geçebilmesi için süreci yöneten, rehberlik eden ya da koordine eden öğretim elemanının da bu beceri konusunda yetkinlik kazanmış olması beklenir.

Öğrenciler tarafından belirtilen bir diğer nitelik ise yaratıcı olmaktır. Bir yaratıcı drama eğitmeninin temel amaçlarından biri de bireyin yaratıcı olmasını sağlamaktır (Adıgüzel, 2018). Bu açıdan ele alındığında bir bireyin yaratıcı yönünün geliştirilebilmesi için eğitmenin ya da öğretim elemanının bu özelliğe sahip olması önemlidir. Dolayısıyla öğrencilerin önemli bir niteliğe dikkat çektikleri söylenebilir. Ayrıca öğrencilerin bir öğretim elemanında olması gereken niteliklerle ilgili olarak alan bilgisine sahip olma ve bu alanla ilgili yöntem ve teknik bilgisine sahip olma gibi iki önemli niteliği vurguladıkları görülmüştür.

Dört farklı üniversitede öğrenim gören öğrencilerin elemanlarının sahip olması gereken nitelikler konusunda ortaklaştıkları tema ve buna bağlı alt temalar incelendiğinde; öğrencilerin sıklıkla kişisel nitelikleri vurguladıkları görülmüştür. Ayrıca araştırma kapsamında öğrencilerin belirttikleri öğretim elemanlarının nitelikleri ile Milli Eğitim Bakanlığı Öğretmen Yetiştirme ve Eğitimi Genel Müdürlüğü tarafından belirlenen Öğretmenlik Mesleği Genel Yeterlikleri kapsamında ele alınan öğretmen yeterliklerinin birçok açıdan örtüştüğü söylenebilir.

Sonuç olarak; bir öğretim elemanın niteliğini ya da mesleki alandaki yeterliliğini en iyi gözlemleyen kişilerin öğrenciler olduğu açıktır. Bu nedenle öğrenci görüşleri açısından öğretim elemanın niteliklerini belirlemek, güvenilir sonuçlar elde edilmesi açısından önemlidir. Ayrıca bir dersin genel amaçları ile öğretim elemanın niteliği arasında bir doğrusallığın olmadığı durumlarda, ders açısından istenilen amaçlara ulaşmanın güçleşeceği savunulabilir. Bu nedenle her bir disiplinin sahip olduğu genel çerçeve ve söz konusu disiplin açısından, ulaşılmak istenen genel amaçlara yol gösteren öğretim elemanının söz konusu amaçlar doğrultusunda bir takım niteliklere sahip olmaları gerekir. Özetle, eğitimin hangi kademesinde olursa olsun dersi vermekle sorumlu olan öğretici konumundaki bireylerin birtakım yeterliklere ya da niteliklere sahip olmaları gerekir. Bu araştırmadan da anlaşılacağı üzere öğrencilerin belirledikleri nitelikleri taşıyan öğretim elemanlarının mesleki yeterlikler açısından da beklentileri büyük ölçüde taşıdıkları söylenebilir. Çalışma sonucunda alan uzmanlarına ve alanda çalışma yapacak olan araştırmacılara şu önerilerde bulunulabilir:

- Üniversitelerde çocuk ve drama dersi veren öğretim elemanlarına yaratıcı drama ile ilgili eğitimler verilebilir.

- Çocuk Gelişimi programlarında yaratıcı drama alanında eğitim almış öğretim elemanlarına görev verilebilir. 
- Bir yaratıcı drama eğitmeninin yeterlikleri ile öğretmen yeterlikleri karşılaştırmalı bir şekilde araştırılabilir.

- Farklı öğretim kademelerinde öğrenim gören öğrencilerin drama eğitmeninin niteliklerine ilişkin görüşleri her öğretim kademesi için ayrı ayrı araştırılabilir.

- Drama eğitmeninin öz yeterlik algıları ile öğrenci görüşleri arasındaki ilişkiyi ele alan araştırmalar yapılabilir.

- Araştırma kapsamında yer alan üniversitelerde öğrenim gören öğrencilerin belirtikleri niteliklerin derslerine giren öğretim elemanları tarafından karşılayıp karşılamadıklarına ilişkin olarak araştırma farklı açıdan ele alınabilir.

- Öğrenciler açısından ders dönemi sonunda öğrenme çıktıları ile öğretim elemanlarının nitelikleri arasındaki ilişki araştırılabilir.

\section{Kaynakça}

Adıgüzel, Ö. (2018). Eğitimde yaratıcı drama. (1. Baskı) İstanbul: Yapı Kredi Yayınları

Başbuğ, S. ve Adıgüzel, Ö. (2019). Müzede yaratıcı drama etkinliklerinin öğrencilerin sosyal bilgiler dersindeki başarılarına etkisi. Yaratıcı Drama Dergisi, 14(1), 1-32

Büyüköztürk, Ş., Kılıç Çakmak E., Akgün, Ö. E., Karadeniz, Ş. ve Demirel, F. (2009). Bilimsel araştırma yöntemleri. (3. baskı). Ankara: Pegem A Yayıncılık.

Çetingöz, D. (2012). Okul öncesi eğitimi öğretmen adaylarının yaratıcı drama yöntemi kullanmaya yönelik özyeterlilkleri. Hacettepe Üniversitesi Eğitim Fakültesi Dergisi, 42(2012), 131-142.

Kara, Ö.T. (2014). Drama lideri olarak Türkçe öğretmeni. Kastamonu Eğitim Dergisi, 22(1), 339-360.

Karasar, N. (2015). Bilimsel araştırma yöntemi. (28. Baskı). Ankara: Nobel Akademik Yayıncılık Eğitim Danışmanlık Tic. Ltd. Şti.

Kasapoğlu, H. (2019). Etkili bir yaratıcı drama liderinin sahip olması gereken özellikler: Katılımcı görüşlerinin nitel analizi. Hacettepe Üniversitesi Ĕgitim Fakültesi Dergisi, 34(1), 106-122. doi:10.16986/ HUJE.2018040671

Keleşoğlu, S. ve Metinnam, İ. (2018). Yaratıcı drama eğitmenlerinin sosyal adalet tutumlarının incelenmesi. Yaratıcı Drama Dergisi, 13(2), 189-198

McCaslin, N. (2016). Yaratıcı drama: sınıf içinde ve dışında. (Çev. Ed. Pınar Özdemir Şimşek), Ankara: Nobel Akademik Yayıncılık. (Eserin orjinali 2006'da yayımlandı).

MEB (2006). Temel eğitime destek projesi “öğretmen eğitimi bileşeni”. Öğretmenlik mesleği genel yeterlikleri. Millı Ĕgitim Bakanlı̆̆ı Tebliğler Dergisi, 69(2590), 1491-1540.

Miles, M. B. and Huberman, A. M. (1994). Qualitative data analysis: An expanded source book. Thousand Oaks: Sage Publications.

Okvuran, A. (2003). Drama öğretmeninin yeterlikleri. Ankara Üniversitesi Eğitim Bilimleri Fakültesi Dergisi, $36(1-2), 81-87$

Ören, M. (2008). Okul öncesinde yaratıcllık ve drama eğitimi, A. Öztürk (Ed.). Okulöncesinde yaratıcıllı̆ı̆ın geliştirilmesi (s. 39-59). Eskişehir: Anadolu Üniversitesi.

Patton, M. Q. (2014). Nitel araştırma ve değerlendirme yöntemleri (Çev. Ed. M. Bütün ve S.B. Demir). Ankara: Pegem A Yayıncılık. (Eserin orjinali 2002'de yayımlandı).

Tutuman, O. Y. (2011). Türkçe öğretmenlerinin yaratıcı drama uygulama yeterlilikleri. Yayımlanmamış yüksek lisans tezi, Dokuz Eylül Ǘniversitesi Eğitim Bilimleri Enstitüsü, İzmir.

Üstündağ, T. (2009). Dramada program gelişstirme. A. Öztürk (Ed.). İlköğretimde drama (s. 75-97). Eskişehir: Anadolu Üniversitesi.

Yıldırım, A. ve Şimşek H. (2013). Sosyal bilimlerde nitel araştırma yöntemleri. (9. Baskı). Ankara: Seçkin Yayıncilik. 